\title{
Aplikasi Seduhan Zingiber Officinale (Jahe) Terhadap Defisit Nutrisi Pada Ibu Hamil Trimester I Di Wilayah Kerja Puskesmas Cikalong kulon Kabupaten Cianjur
}

\author{
Siti Nuraini ${ }^{*}$, Dhinny Novryanthi ${ }^{2}$, Eva Martini ${ }^{3}$ \\ ${ }^{1}$ Universitas Muhammadiyah Sukabumi \\ ${ }^{2}$ Universitas Muhammadiyah Sukabumi \\ ${ }^{3}$ Universitas Muhammadiyah Sukabumi \\ Email : ${ }^{1}$ sit.nur2209@gmail.com
}

\begin{abstract}
Abstrak
Selama masa kehamilan ibu mengalami perubahan fisik, sosial dan emosional di lingkungan keluarga. Setiap kehamilan juga dapat berkembang menjadi masalah atau komplikasi setiap saat. Itu sebabnya mengapa ibu hamil memerlukan pemantauan selama kehamilannya Perubahan hormonal wanita terjadi pada saat kehamilan yaitu terjadinya peningkatan hormon progesteron, dan estrogen, sehingga menghasilkan HCG plasenta atau (Human Chorionic Gonadotropine). Hal ini dapat menimbulkan keluhan yang akan dialami oleh ibu hamil, salah satunya adalah emesis gravidarum atau mual dan muntah yang terjadi pada kehamilan dapat menimbulkan gangguan nutrisi, dehidrasi, kelemahan, penurunan berat badan, serta ketidakseimbangan elektrolit pada tubuh yang dapat menimbulkan dampak buruk pada perkembangan janin seperti abortus, bayi dengan berat badan lahir rendah, kelahiran prematur, malformasi pada janin, pertumbuhan janin terhambat. Tujuan dari penelitian ini yaitu untuk memahami dan mengaplikasikan seduhan zingiber officinale (jahe) terhadap defisit nutrisi pada ibu hamil trimester I. Metode pengumpulan data berupa wawancara, observasi, dan studi lateratur/dokumentasi. Intervensi yang dilakukan untuk mengatasi mual muntah dengan seduhan jahe (zingiber officinale) untuk memenuhi kebutuhan nutrisi pada ibu hamil. Dapat disimpulakan bahwa pemberian seduhan jahe (zingiber officinale) dapat menurunkan mual muntah pada ibu hamil trimester I. Hasil penelitian ini diharapkan dapat menjadi reperensi bagi peneliti selanjutnya.
\end{abstract}

Kata kunci : jahe, kehamilan, mual muntah

\section{Abstrack}

During pregnancy, mothers experience physical, social and emotional changes in the family environment. Any pregnancy can also develop into problems or complications at any time. That's why pregnant women need monitoring during pregnancy. Hormonal changes in women occur during pregnancy, namely an increase in the hormones progesterone and estrogen, resulting in placental HCG or (Human Chorionic Gonadotropine). This can cause complaints that will be experienced by pregnant women, one of which is emesis gravidarum or nausea and vomiting that occurs in pregnancy can cause nutritional disorders, dehydration, weakness, weight loss, and electrolyte imbalances in the body which can have a negative impact on development. such as abortion, low birth weight babies, premature birth, malformations of the fetus, stunted fetal growth. The purpose of this study was to understand and apply the infusion of zingiber officinale (ginger) to nutritional deficits in first trimester pregnant women. Data collection methods were interviews, observation, and lateral/documentation studies. Interventions were carried out to overcome nausea and vomiting by steeping ginger (zingiber officinale) to meet the nutritional needs of pregnant women. It can be concluded that the administration of steeping ginger (zingiber officinale) can reduce nausea and vomiting in pregnant women in the first trimester. The results of this study are expected to be a reference for future researchers.

Keywords: ginger, nausea vomiting, pregnancy 


\section{Pendahuluan}

Masa kehamilan dimulai dari konsepsi sampai lahirnya janin. Lamanya hamil normal adalah 280 hari (40 minggu atau 9 bulan 7 hari) dihitung dari hari pertama haid terakhir. Kehamilan dibagi dalam 3 triwulan pertama dimulai dari konsepsi sampai tiga bulan, triwulan kedua dari bulan keempat sampai 6 bulan, triwulan ketiga dari bulan ketujuh sampai 9 bulan. Gartika \& Sari, (2012). Selama hamil ibu mengalami perubahan fisik, sosial dan emosional di lingkungan keluarga. Setiap kehamilan juga dapat berkembang menjadi masalah atau komplikasi setiap saat. Itu sebabnya mengapa ibu hamil memerlukan pemantauan selama kehamilannya (Maternity et al., 2018). Perubahan hormonal wanita terjadi pada saat kehamilan yaitu terjadinya peningkatan hormon progesteron, dan estrogen, sehingga menghasilkan HCG plasenta atau (Human Chorionic Gonadotropine). Hal ini dapat menimbulkan keluhan yang akan dialami oleh ibu hamil, salah satunya adalah emesis gravidarum (Manuaba et al., 2015).

Menurut hasil laporan National Vital Statistic Report (2016) jumlah kehamilan di Amerika Serikat di perkirakan 4.348.949 orang (Misrawati, dkk : 2015). Berdasarkan Kementrian Kesehatan Republik Indonesia tahun 2018, jumlah kehamilan di Indonesia mencapai 5.291.143 orang. Jumlah ibu hamil di Provinsi Jawa Barat tahun 2018 sebesar 966.319 orang (Kemenkes RI, 2018). Prevalensi ibu hamil menurut data Riset Kesehatan Dasar Provinsi Jawa Barat tahun 2018, jumlah ibu hamil di Cianjur mencapai 6,56\% (Riskesdas, 2018).

Hiperemesis gravidarum adalah suatu kondisi yang biasa muncul mulai usia kehamilan 4 minggu dan berakhir pada usia kehamilan 4 sampai 16 mingu. Hampir 50-90\% wanita hamil mengalami mual muntah pada trimester pertama. Mual dan muntah dianggap sebagai sebuah konsekuensi diawal kehamilan yang dapat menimbulkan dampak pada wanita. Separuh dari wanita hamil hanya karna mencium bau makanan tertentu akan mengalami mual muntah. Pada primipara mual dan muntah terjadi $60-80 \%$ dan pada multipara 40-60\%. Hutahaen, (2013). Mual dan muntah pada kehamilan dapat menimbulkan gangguan nutrisi, dehidrasi, kelemahan, penurunan berat badan, serta ketidakseimbangan elektrolit pada tubuh ibu yang dapat menimbulkan dampak buruk pada perkembangan janin seperti abortus, bayi dengan berat badan lahir rendah, kelahiran prematur, malformasi pada janin, pertumbuhan janin terhambat (Intra Uterine Growth Retardation/IUGR)

Dari total seluruh kehamilan di dunia menurut WHO (World Health Organization) terdapat $12,5 \%$ jumlah kejadian hiperemesis gravidarum (WHO, 2013). Berdasarkan survey demografi dan kesehatan Indonesia (SDKI) di Indonesia di peroleh data ibu dengan hiperemesis gravidarum mencapai 14,8\% Berdasarkan data profil kesehatan Indonesia tahun 2015. Menurut data bidang pelayanan kesehatan dinas kesehatan Provinsi Jawa Barat pada tahun 2012 prevalensi hipermesis graviarum di jawa barat pada ibu hamil yaitu sekitar 60-80\% (Dinkes Jawa Barat, 2012). Di wilayah Kerja Puskesmas Cikalongkulon terdapat sekitar 60-80 \% ibu hamil trimester I yang mengalami hyperemesis gravidarum.

Rasa mual muncul dikarenakan aliran darah menerima peningkatan hormon yang tiba-tiba. Rasa mual dapat dirasakan pagi atau malam hari, atau malah sepanjang hari. Ibu mungkin akan kehilangan nafsu makan, (Hutahaen, 2013). Sehingga dari mual muntah, dan tidak nafsu makan yang akan mengakibatkan defisit nutrisi pada iubu hamil.

Mual muntah ini dapat diatasi melalui tindakan farmakologi maupun non farmakologi. Tindakan non farmakologi yang bisa di sarankan oleh tenaga kesehatan seperti menganjurkan ibu hamil mengkonsumsi jahe dalam bentuk seduhan jahe, teknik relaksasi, dan aroma terapi (Lazzdia \& Putri, 
2020).

Jahe merupakan salah satu cara untuk meredakan mual dan muntah selama kehamilan, setidaknya meminimalisasi gangguan ini. Menurut sebuah ulasan yang dipublikasikan oleh jurnal obstetrik dan ginekologi, jahe dapat membantu para wanita hamil mengatasi derita morning sinkness tanpa menimbulkan efek samping yang membahayakan janin di dalam kandungannya. Jahe memiliki khasiat untuk mencegah penyakit dan membuang racun (profiklalsis dan detoksifikasi). (Utami, P, 2012). Jahe juga mengandung minyak atsiri yang menmpunyai efek menyegarkan yang dapat memblokir reflek muntah Ginting, A. (2020).

Berdasarkan hasil studi pendahuluan yang telah peneliti lakukan di wilayah kerja Puskesmas Cikalongkulon Kabupaten Cianjur terdapat prevalensi yan cukup tinggi terkait kasus ibu hamil dengan hiperemesis gravidarum yaitu dengan presentase sekitar 60-80\%. Berdasarkan latar belakang masalah di atas dan studi pendahuluan maka peneliti tertarik untuk melakukan penelitian tentang "Aplikasi Seduhan Zingiber Officinale (Jahe) Terhadap Defisit Nutrisi Pada Ibu Hamil Trimester I Di Wilayah Kerja Puskesmas Cikalongkulon Kabupaten Cianjur".

\section{Metode Penelitian}

Jenis penelitian yang digunakan dalam peneltian ini adalah studi kaus. Studi Kasus ialah metode penelitian studi penelaahan kasus. (case study) merupakan studi yang dilakukan dengan cara meneliti suatu (Notoatmodjo, 2012).

Teknik yang dilakukan dalam penelitian ini adalah purposive sampling yakni suatu teknik penetapan sampel dengan cara memilih sampel di antara populasi sesuai dengan yang dikehendaki peneliti (tujuan/masalah dalam penelitian), sehingga sampel tersebut dapat mewakili karakteristik populasi yang telah dikenal sebelumnya (Nursalam, 2016 p.174). Sampel yang diambil dalam penelitian ini adalah satu orang ibu hamil trimester I yang mengalami mual muntah pada ibu hamil di Wilayah Kerja Puskesmas Cikalongkulon Kabupaten Cianjur. Lama penelitian 2 bulan, sedangkan lamanya tindakan senam hamil dilakukan sebanyak 2 kali dalam satu hari dengan waktu 3 hari. Pengumpulkan data dilakukan melalui observasi, melakukan wawancara langsung kepada klien, dan studi kepustakaan dengan mencari referensi teori yang relevan dengan kasus atau permasalahan yang di temukan.

\section{Hasil}

Hasil penelitian menunjukan adanya pengaruh seduhan jingiber officinale (jahe) terhadap penurunan mual muntah pada ibu hamil trimester I yang diberikan 2 kali dalam sehari selama 3 hari. Berdasarkan hasil analisa data umum mual muntah pada ibu hamil trimester I sebelum dan sesudah di berikan seduhan zingiber officinale (jahe) diwilayah kerja Puskesmas Cikalongkulon Kabupaten Cianjur dengan 1 responden sebagai berikut : 


\begin{tabular}{lll}
\hline Kunjungan & Sebelum pemberian & Sesudah pemberian \\
\hline Kunjungan ke-1 & $5-6 \times$ dalam sehari & $4-5 \times$ dalam sehari \\
Kunjungan ke-2 & 4-5 x dalam sehari & $3-4 \times$ dalam sehari \\
Kunjungan ke-3 & 3-4 x dalam sehari & 1-2 x dalam sehari \\
\hline
\end{tabular}

Dari data di atas menunjukan bahwa mual muntah pada ibu hamil trimester I dengan meminum seduhan zingiber officinale ( jahe) didapatkan hasil bahwa setelah diberikan intervensi seduhan jahe tampak ada penurunan mual muntah dibuktikan dengan sebelum dilakukan intervensi seduhan jahe di kunjungan ke-1 mual muntah 5-6 kali dalam sehari serta klien tidak nafsu makan. Setelah diberikan seduhan jahe klien mengalami penurunan mual muntah di kunjungan ke-3 dengan hasil mual muntah berkurang, mual muntah berkurang serta klien tampak menghabiskan $1 / 2$ porsi makan, mukosa bibir lembab dan terjadi kenaikan berat badan dengan frekuensi mual muntah 1-2 kali dalam sehari.

Maka terjadi penurunan 4 angka yang dilakukan selama 2 kali dalam sehari selama 3 kali kunjungan. Ini membuktikan bahwa ada perbedaan mual muntah sebelum dan sesudah diberikan seduhan jahe memberikan pengaruh terhadap penurunan mual muntah pada ibu hamil trimester I, Sebelum diberikan seeduhan jahe terdapat mual muntah 5-6 kali dalam sehari.

\section{Pembahasan}

Pada tahap pengkajian, peneliti memulai pengumpulan data pada klien dan mendapatkan hasil data sebagai berikut, klien sedang hamil 11 minggu (Trimester I), G1P0A0 klien mengeluh mual muntah sebanyak 5-6 kali dalam sehari juga penurunan nafsu makan dan penurunan berat badan menjadi keluhan yang dialami oleh klien.

Menurut teori Khayati, (2013) serta Putri dkk (2017) menyataka mual dan muntah saat hamil, yang bisa terjadi hingga lebih dari 3-4 kali sehari. Kondisi ini bisa sampai mengakibatkan hilangnya nafsu makan dan penurunan berat badan. Muntah yang berlebihan juga dapat menyebabkan ibu hamil merasa pusing, lemas, dan mengalami dehidrasi serta ketidaknyamanan yang sering terjadi pada ibu hamil trimester I sering buang air kecil, kelelahan keputihan sering terjadi, mengidam , mual muntah. (Marmi, 2011). Sehingga dari mual muntah bisa mengakibatkan defisit nutrisi pada ibu hamil. Hal ini menunjukkan bahwa tidak terjadi kesenjangan antara hasil data pengkajian yang didapatkan peneliti dengan teori.

Pada tahap perencanaan dan pelaksanaan peneliti lebih memfokuskan pada permasalahan mual muntah yang di alami klien, yaitu dengan menyusun perencanaan diantaranya mengkaji tanda- tanda vital, monitor asupan makanan, serta meberikan teknik nonfarmakologi seduhan zingiber officinale (jahe).

Hal ini membuktikan bahwa ada pengaruh dalam memberikan seduhan jahe untuk menurunkan mual muntah, hal ini sejalan dengan hasil penelitian Pebrianthy \& Ritonga, (2021) serta Yanuaringsih, dkk (2020) dimana hasil penelitian tersebut menggambarkan adanya hasil signifikan setelah meminum seduhan jahe (zingiber offcinale) pada beberapa responden yang diambil oleh teori tersebut adanya penurunan mual muntah setelah dilakukan intervensi seduhan jahe (zingiber offcinale).

Jadi seduhan jahe (zingiber offcinale) berpengaruh terhadap penurunan mual muntah pada klien dengan hyperemesis gravidarum pada trimester 1. ini terjadi karena Terdapat 6 senyawa di dalam jahe telah terbukti memiliki aktivitas antiemetik (anti mual). Kerja senyawa tersebut lebih mengarah pada dinding lambung dari pada sistem saraf pusat. Kandungan didalam jahe terdapat minyak atsiri 
zingiberena (zingirona), zingerol, zingiberol, zingiberin, vitamin $\mathrm{A}, \mathrm{B}, \mathrm{C}$, dan resin pahit yang dapat memblok serotonin yaitu suatu neurotransmiter yang disintesiskan pada neuron seretonergis dalam sistem saraf pusat dan sel-sel enterokromarfn dalam saluran pencernaan, sehingga dapat dipercaya sebagai pengurangan rasa mual muntah (Hasanah, 2015).

\section{Simpulan}

Adanya pengaruh yang signifikan terhadap pemberian seduhan zingiber officinale (jahe) pada seorang ibu hamil trimester I dengan keluhan mual muntah. Perbedaan frekuensi mual muntah sebelum dan sesudah diberikan seduhan zingiber officinale (jahe) pada ibu hamil trimester I di Wilayah Kerja Puskesmas Cikalingkulon Kabupaten Cianjur. Yaitu dari pertemuan pertama yaitu 56 kali dalam sehari dan pada pertemuan ketiga menjadi 1-2 kali dalam sehari, terjadi penurunan mual muntah yang dilakukan selama 2 kali dalam sehari selama 3 kali kunjungan.

\section{Referensi}

Dermawan, D. (2012). Proses Keperawatan Penerapan Konsep \& Kerangka Kerja (1st ed.). Gosyen Publishing.

Dinarti \& Mulyanti, 2017. (2017). DokumentasiKeperawatan. Kementrian Kesehatan Republik Indonesia.

Dinarti dan Mulyanti, Y. (2017). Dokumentasi Keperawatan (1st ed.). Kementerian Kesehatan Republik Indonesia.

Dinkes Jawa Barat, (2012). Profil Kesehatan Provinsi Jawabarat Tahun 2012. (Https://Www.Depjes.Go.Id.Profil_Kes.Prov.Jawabarat_2012.Pdf.)

Gartika, R. S. (2012). 9 Bulan penuh Keajaiban Selama kehamilan Edisi terbaru, Gudang Ilmu.

Holmes Dobble . 2011. “Buku Ajar Ilmu Kebidanan”. EGC

Hutahaean. (2013). Perawatan Antenatal. Salemba Medika.

Irianti, D. (2014). Asuhan Kebidanan Berbasis Bukti. Sagung seto.

Manuaba, I. A. C., Manuaba, I. B. G. F., \& Manauba, I. B. G. (2015). Ilmu Kebidanan Penyakit Kandungan Dan KB Untuk Pendidikan Bidan. EGC.

Marmi. (2011). Asuhan kebidanan pada masa antenatal. Pustaka Pelajar.

Megasari, dkk. (2015). Buku ajar metodologi penelitian kebidanan.

Mitayani. (2011). Asuhan keperawatan maternitas. Salemba Medika

Mochtar, R. (2011). Sinopsis Obstetri Jilid I. EGC.

Padila. (2011). Buku Ajar Keperawatan Maternitas. Nuha Medika. 
Sondakh Jenny J.S. 2013. Asuhan Kebidanan Persalinan \& Bayi Baru Lahir. Erlangga

Sugiyono. (2015). Metode Penelitian Kuantitatif. Kualitatif dan R\&D. Alfabeta.

Sunarti. (2013). Asuhan Kehamilan. In media.

Suryadi, Didih. (2011). Promosi Efektif "Menggugah Minat \& Loyalitas Pelanggan". PT. Suka Buku.

Suryati. (2011). Asuhan Kebidanan I Konsep Dasar Asuhan Kehamilan. Nuha Medika.

Tiran (2015). Seri Asuhan Kebidanan Mual dan Muntah Kehamilan. EGC

Pokja SDKI DPP PPNI. (2017). Standar Diagnosis Keperawatan Indonesia Definisi dan Indikator Diagnostik. Dewan Pengurus PPNI

Tim Pokja SIKI DPP PPNI. (2018b). Standar Intervensi Keperawatan Indonesia: Definisi dan Tindakan Keperawatan. Dewan Pengurus Pusat Persatuan Perawat Nasional Indonesia.

Utami, P. (2012). Antibiotik Alami untuk Mengatasi Aneka Penyakit. AgroMedia Pustaka.

Wiraharja, RS, D. (2011). Kegunaan Jahe Untuk Mengatasi Gejala Mual Dalam Kehamilan.

WHO. (2013). Reduction Of Maternal Mortality. A Joint WHO/ UNFPA/ UNICEF/ World Bank Statement.

Ardani, A. (2014). Perbandingan Efektifitas Pemberian Terapi Minuman Jahe dengan Minuman Kapulaga terhadap Morning Sickness pada Ibu Hamil Trimester I di Kelurahan Ngempon Kecamatan Bergas Kabupaten Semarang.

Artika, T. (2016). Hubungan Hiperemesis Gravidarum dengan Usia Ibu, Usia Gestasi, Paritas, dan Pekerjaan pada Pasien Rawat Inap di RSUP Dr. Moh. Hoesin Palembang.

Astuti, N. D.\& Elsanti, D. (2016). Hubungan Antara Dukungan Sosial Dengan Emesis Gravidarum Pada Ibu Hamil Trimester I Di Puskesmas Kembaran I Kabupaten Banyumas.

Ginting, A. (2020). Pengaruh Pemberian Jahe Emprit Dalam Mengurangi Hiperemesis Gravidarum Pada Ibu Hamil Di Klinik Nana Diana Kota Medan Tahun 2019. Stindo Profesional, VI(4), 3-7.

Harahap, R. F., Dani, L., Alamanda, R., Harefa, I. L., \& Indonesia, U. P. (2020). Pengaruh Pemberian Air Rebusan Jahe Terhadap Penurunan Mual dan Muntah Pada Ibu Hamil Trimester I. Jurnal Ilmu Keperawatan, 8, 84-95.

Kunci, K., Gravidarum, H., \& Jahe, M. (2019). Efektivitas Minuman Jahe Terhadap Emesis Gravidarum Pada Ibu Hamil Trimester I Di Puskesmas Kilasah Provinsi Banten Tahun 2019. 3(2), 157-163.

Lazdia, W., \& Putri, N. E. (2020). Pengaruh Jahe Hangat Dalam Mengurangi Mual, Muntah Ibu Hamil Dengan Hipermesis Gravidarum. REAL in Nursing Journal (RNJ),3(1),30-39. https://ojs.fdk.ac.id/index.php/Nursing/i ndex 
Pebrianthy, L., \& Sitonga, N. (2021). Efektivitas Seduhan Zingiber Offcinale (Jahe) Dalam Mengatasi Mual Muntah pada Kehamilan Trimester 1. Jurnal Akademika Baiturrahim Jambi, 10(1), 176.

https://doi.org/10.36565/jab.v10i1.297 Putri, A. D., Andiani, D., Kesehatan, F. I., Parepare, U. M., \& Selatan, S. (2017). Efektifitas pemberian jahe hangat dalam mengurangi frekuensi mual muntah pada ibu hamil trimester i. 978-979.

Ramadhani, I. P., \& Ayudia, F. (2019). Pengaruh Pemberian Minuman Jahe (Zingiber Officinale Var. Rubrum) Terhadap Penurunan Emesis Gravidarum Trimester Pertama. Jik- Jurnal Ilmu Kesehatan, 3(2), 97. https://doi.org/10.33757/jik.v3i2.231

Rufaridah, A., Herien, Y., \& Mofa, E. (2019). Pengaruh Seduhan Zingiber Offcinale (Jahe) Terhadap Penurunan Emesis Gravidarum. Jurnal Endurance, 4(1),204. https://doi.org/10.22216/jen.v4i1.3505 